\title{
HAEMOLYSIS BY URINARY ESCHERICHIA COLI AND VIRULENCE IN MICE
}

\author{
J. F. van den Bosch, P. Postma, J. De GraafF* and D. M. MacLaren \\ Department of Medical Microbiology and * Department of Oral Microbiology, School of \\ Medicine, Free University, 1007 MC Amsterdam, The Netherlands
}

\section{Plate XVIII}

\begin{abstract}
Summary. The influence of haemolysin production on virulence was studied in an experimental mouse model. Urinary strains of Escherichia coli can be divided into three virulence groups by determining their kinetics in the mouse kidney after intravenous injection. Virulent strains of groups II and III were more often haemolytic than avirulent group-I strains. Haemolytic virulent strains often caused haemoglobinuria in the mice, and killed the mice more rapidly than did non-haemolytic virulent strains. No relationship was found between $\alpha$-haemolytic activity and virulence in wild-type haemolytic strains. When haemolysin production was reduced or eliminated by treatment with actinomycin-D or rifampicin, six out of seven group-II strains tested gave the same results as avirulent group-I strains. However, the kinetics in the mouse kidney of four haemolytic group-III strains tested was not changed after reduction or elimination of haemolysin production; only a small decrease in toxicity was observed. It is concluded that haemolysin production by $E$. coli is a decisive virulence factor in most of the mouse-nephropathogenic group-II strains, but not in the virulent group-III strains.
\end{abstract}

\section{INTRODUCTION}

Haemolysin production is a general phenomenon found in many strains of Escherichia coli. Four different haemolysins have been described (Jorgensen et al., 1976), and the most important types produced by E. coli are $\alpha$ and $\beta$ haemolysins. The $\alpha$ haemolysin is a cell-free, filtrable protein, produced during log-phase growth by modification of a precursor molecule present in fresh meat and blood (Lovell and Rees, 1960; Smith, 1963; Snyder and Koch, 1966; Short and Kurtz, 1971; Zwadyk and Snyder, 1971; Rennie and Arbuthnott, 1974; Williams, 1979). The $\beta$ haemolysin is cell associated; its activity cannot be dissociated from intact bacteria and appears to be closely associated with cell metabolism (Smith, 1963; Short and Kurtz, 1971). Several studies have indicated that haemolysis may be a virulence factor of $E$. coli and may play a role in the pathogenesis of urinary-tract infections. Dudgeon, 
Wordley and Bawtree $(1921,1922)$ reported that haemolytic strains of $E$. coli were much commoner in urinary-tract infections in the male than in the female. Cooke and Ewins (1975) and Minshew et al. (1978a and $b$ ) found that strains of $E$. coli causing urinary-tract infections were haemolytic more commonly than faecal strains.

In a previous study we found differences in virulence between different strains of $E$. coli in a mouse model (van den Bosch, de Graaff and MacLaren, 1979). We were able to divide the strains into three virulence groups on the basis of the kinetics of the viable counts in the kidney and other organs after intravenous injection, and the measurement of LD50 values and killing times.

In the present study we have investigated the relationship between haemolysin production by $E$. coli and virulence in the experimental mouse model.

\section{MATERIALS AND METHODS}

Bacterial strains. The 55 strains of $E$. coli used in this study were isolated from cases of urinary-tract infection either in general practice or in hospital patients, and were described previously (van den Bosch et al., 1979, 1980a and $c$ ). Strains AD27 and AD27b were kindly supplied by Dr L. Emödy (University of Pécs, Hungary), and were originally numbered P673 and $\mathrm{P} 673 / 1$.

Screening for haemolysis and assay of $\alpha$-haemolytic activity. Haemolysis was tested on washed-blood agar plates. Defibrinated sheep blood (Gibco, Glasgow) was washed three times in phosphate-buffered saline (PBS, $p \mathrm{H} \mathrm{7.0)}$ ) and added to Blood Agar Base No. 2 (Oxoid) to give a final concentration of $5 \%(\mathrm{v} / \mathrm{v})$. After incubation overnight at $37^{\circ} \mathrm{C}$, haemolysis was scored on a scale from - to $+++(-=$ no haemolysis; $+=$ lysis only underneath the colonies; $++=$ a small zone of lysis around the colonies; $+++=$ a large zone of lysis).

The $\alpha$-haemolytic activity was determined as described by van den Bosch et al. (1980b). The $\alpha$-haemolytic activity of a strain was defined as the highest dilution of the crude $\alpha$-haemolytic supernate that showed a haemoglobin release of at least $25 \%$ of the maximal haemoglobin release from the erythrocyte suspensions (MHR25).

Elimination of haemolysin production. Experiments to eliminate haemolysis from $E$. coli were done according to the method described by Mitchell and Kenworthy (1977). Bacteria were grown overnight in Nutrient Broth (Oxoid) at $37^{\circ} \mathrm{C}$, diluted to a density of $10^{5}$ bacteria $/ \mathrm{ml}$, and $0.1 \mathrm{ml}$ of this suspension was added to $10 \mathrm{ml}$ of nutrient broth containing actinomycin-D (40 $\mu \mathrm{g} / \mathrm{ml}$ or more) or rifampicin ( $3 \mu \mathrm{g} / \mathrm{ml}$ or more). Cultures were sampled after $24 \mathrm{~h}$ and, if necessary, after $48 \mathrm{~h}$; they were diluted in PBS and plated on to washed-blood agar to yield separate colonies. When colonies with altered haemolytic activity were not found, a few drops of the culture were transferred to fresh nutrient broth with the agent under test, and the procedure was repeated. For each strain actinomycin-D was used first, up to a concentration of $200 \mu \mathrm{g} / \mathrm{ml}$. When elimination of haemolysin production was not observed, rifampicin was subsequently used, up to a maximum concentration of $30 \mu \mathrm{g} / \mathrm{ml}$. Colonies with altered haemolysis were tested for growth rate, biotype, serotype, antibiotic-sensitivity pattern, colicine production and haemagglutination pattern. Growth rates in nutrient broth were tested by following the optical density at $650 \mathrm{~nm}$. Biotypes were determined by the API 20E system (API system S.A., Montalieu Vercieu, France). Serotypes ( $O$ and $K)$ were determined by P. A. M. Guinee and W. H. Jansen at the National Institute of Public Health, Bilthoven, The Netherlands. The antibiotic-sensitivity patterns with seven antibiotics were determined by the agar-diffusion technique on antibiotic-sensitivity medium with paper disks (AB Biodisk, Solna, Sweden). Colicine production was tested against E. coli Row strain PC 1408, which is sensitive to all known colicines and originated from Frédéricq (Phabagen Collection, Laboratory for Microbiology, Utrecht, The Netherlands). Colonies were killed with chloroform, and overlaid 
with soft nutrient agar $(0.6 \%(\mathrm{w} / \mathrm{v})$ agar) containing a 50 -fold dilution of an overnight culture of indicator strain PC1408. Inhibition zones were read after overnight incubation at $37^{\circ} \mathrm{C}$. To test the haemagglutination pattern, bacteria grown overnight in nutrient broth with gentle agitation and on washed-blood agar plates were harvested and resuspended in PBS to a concentration of $10^{9}$ bacteria $/ \mathrm{ml}$. Serial twofold dilutions were made in $100-\mu$ l volumes of PBS, and $100 \mu \mathrm{l}$ of $0.5 \%$ guinea-pig or human group-A erythrocytes, washed in PBS, was added to each dilution. The mannose sensitivity of the haemagglutination was tested by addition of $1 \%$ D-mannose to the erythrocyte suspensions. Agglutination was read after incubation for $2 \mathrm{~h}$ at $0^{\circ} \mathrm{C}$.

Virulence test. The virulence of the strains was tested as described by van den Bosch et al. (1979). Approximately $2.5 \times 10^{8} \log$-phase cells of the test strains were injected intravenously into mice, and the viable counts in the mouse kidney were measured at different intervals up to 8 $\mathrm{h}$ after injection. Avirulent group-I strains show low counts throughout the experiment; mouse nephropathogenic group-II strains show high counts in the kidney after an initial decline; and the most virulent group-III strains show high counts immediately after injection which remain high. Two mice were included in each assay to determine whether they survived the inoculum.

\section{RESULTS}

\section{Haemolysin production and virulence}

Fifty-five urinary strains of $E$. coli were tested for haemolysin production on washed-blood agar and for virulence. The distribution of haemolytic and nonhaemolytic strains amongst the three virulence groups is shown in table I. Virulent group-II and group-III strains were haemolytic more often than avirulent group-I strains $\left(\chi^{2}\right.$ test on a $2 \times 3$ table, $\left.p=0 \cdot 002\right)$. All haemolytic strains produced $\alpha$ haemolysin. The relationship between $\alpha$-haemolytic activity and virulence is shown in fig. 1 . Systematic differences in $\alpha$-haemolytic activity could not be shown between haemolytic strains from different virulence groups $\left(\chi^{2}\right.$ test on mean scores, $\left.\mathrm{p}=0.52\right)$.

Table II shows the time to death for the mice challenged with haemolytic or nonhaemolytic strains from the different virulence groups. Within each virulence group, the haemolytic strains killed the mice more rapidly than the nonhaemolytic strains. Furthermore, we observed that two-thirds of the haemolytic virulent strains (groups II and III) caused macroscopic haemoglobinuria in the mice within $8 \mathrm{~h}$ after injection; this was not observed with nonhaemolytic strains nor with the four haemolytic but avirulent group-I strains. Amongst the haemolytic strains, there was no relationship between

TABLE I

Distribution of haemolytic and nonhaemolytic strains of E. coli amongst virulence groups $I, I I$ and III

\begin{tabular}{l|ccc}
\hline \multirow{2}{*}{$\begin{array}{c}\text { Haemolytic } \\
\text { activity }\end{array}$} & \multicolumn{3}{|c}{ Number of strains in virulence group* } \\
\cline { 2 - 4 } & I & II & III \\
\hline $\begin{array}{l}\text { Haemolytic } \\
\text { Nonhaemolytic }\end{array}$ & 20 & 11 & 9 \\
\end{tabular}

* Group I = avirulent strains; group II = mouse-nephropathogenic strains; group III = virulent strains. 


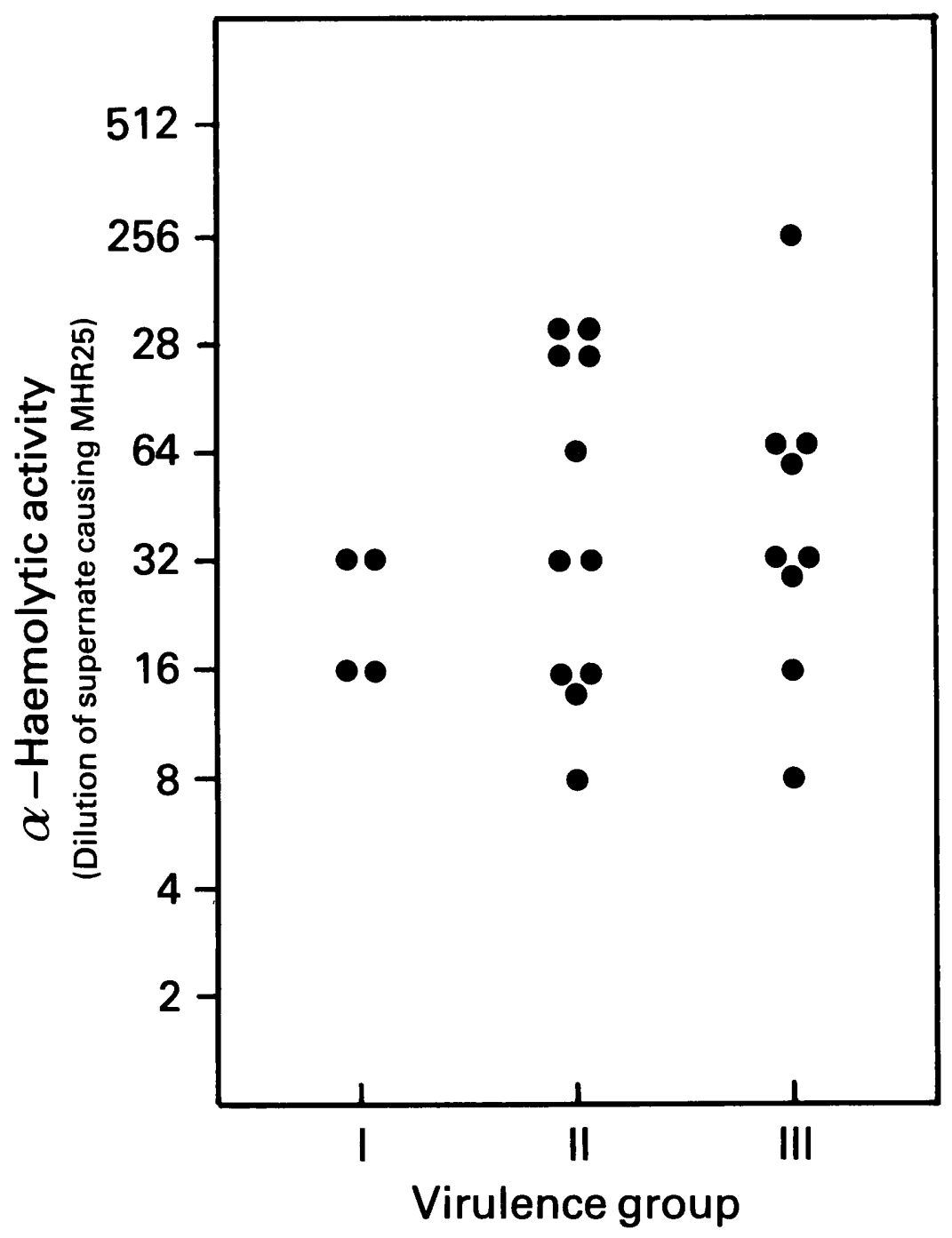

FIG. 1. $-\alpha$-Haemolytic activity of haemolytic strains of $E$. coli belonging to the three virulence groups. MHR25 $=25 \%$ of maximal haemoglobin release; see Methods.

$\alpha$-haemolytic activity and the time to death, or between $\alpha$-haemolytic activity and haemoglobinuria.

\section{Elimination of haemolysin production}

The results of the elimination experiments on haemolytic strains varied between the strains tested. A reduction of haemolysin production was achieved in most strains. However, the agent and the concentration of agent required differed between strains; with actinomycin-D, concentrations from 40 
TABLE II

Time to death for mice challenged with haemolytic and nonhaemolytic E. coli strains of different virulence groups

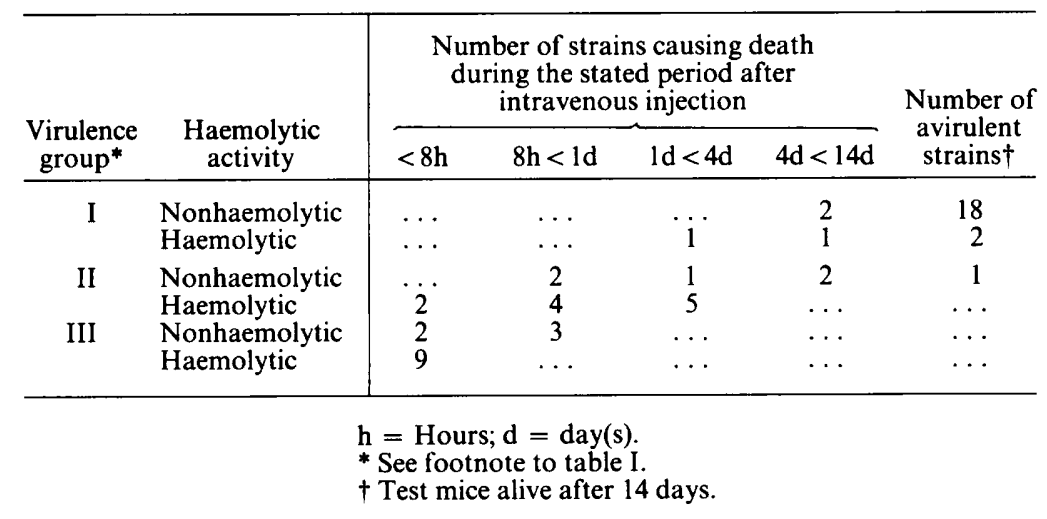

to $200 \mu \mathrm{g} / \mathrm{ml}$ were required and the frequency of elimination ranged from $<1 \%$ to $>50 \%$. Two colony types with altered haemolysis were found: (a) a colony with a smaller zone of lysis on blood agar compared with the wild-type haemolytic strain, and (b) a nonhaemolytic colony (fig. 2). Most of the variants with reduced haemolytic activity still produced $\alpha$ haemolysin; only one produced only $\beta$ haemolysin.

Before the variants with altered haemolysis were tested for virulence in the mouse model, they were characterised by determination of several features; these were growth rate, biotype, serotype, antibiotic-sensitivity pattern, colicine production and haemagglutination pattern. The only character that sometimes changed with the change of haemolytic activity was the serotype; some variants lost their $\mathrm{K}$ antigen. This was not restricted to any particular $\mathrm{K}$ antigen and was observed with $\mathrm{K}$ types 2, 23 and 95.

\section{Effect of altered haemolysin production on virulence}

Virulence tests were done on variants in which altered haemolysin production was the only change observed. For all but one strain, a control isolate treated with the agent but with no change in haemolysin production or other character, was also tested. All variants were stable in vitro and after passage through the mouse.

Fig. 3 shows an example of the effect of changing the haemolytic activity on the virulence of a mouse-nephropathogenic group-II strain (AD109). The behaviour in the mouse kidney of the wild-type haemolytic strain and of the control strain, treated with the agent but not changed in haemolytic activity, were similar. However, the variant with reduced haemolytic activity and the nonhaemolytic variant behaved as avirulent group-I strains. The effect of 


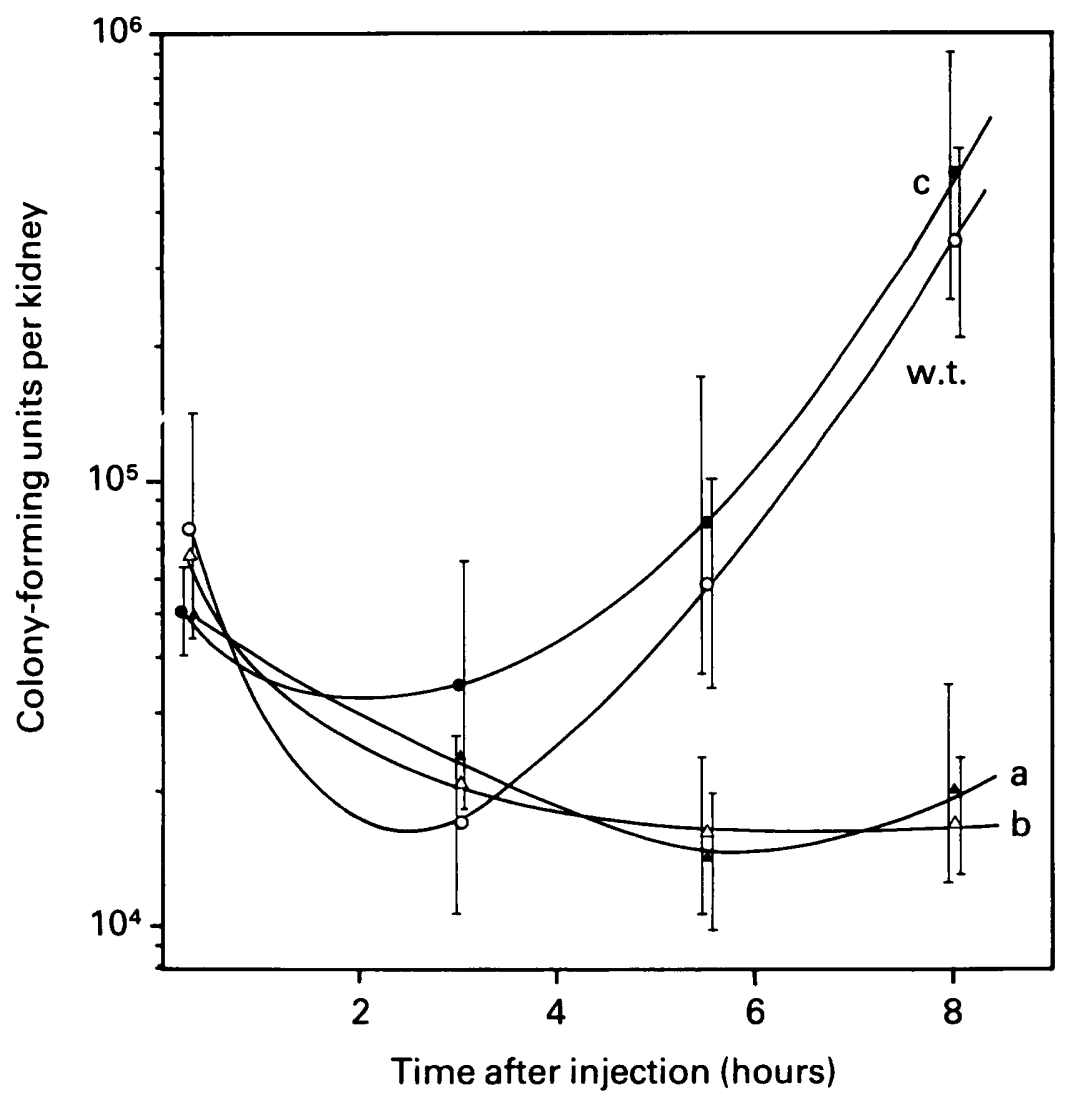

FIG. 3.-Effect of reduction and elimination of haemolysin production on the virulence of group-II strain AD109 for the mouse kidney. w.t. = Wild-type haemolytic strain; $a=$ variant with reduced haemolytic activity; $b=$ nonhaemolytic variant; $c=$ control stain with no change in haemolysis.

reducing or abolishing the haemolysin production on the virulence of five out of another six group-II strains was similar (table III). The only exception was strain AD336: the nonhaemolytic variant behaved in the mouse kidney as the haemolytic parent strain. In addition to the change of most group-II strains into group I, the time to death of the mice challenged with the variants with reduced or abolished haemolytic activity was longer than the time with the haemolytic wild-type and control strains. Furthermore, the haemoglobinuria seen in mice challenged with some haemolytic wild-type and control strains was not observed after injection of variants with reduced haemolytic activity or nonhaemolytic variants.

Fig. 4 shows an example of the effect of reduced haemolysin production on the virulence of a group-III strain (AD121). The behaviour in the mouse kidney of the wild-type haemolytic strain, the haemolytic control isolate, the variant with reduced haemolytic activity and the nonhaemolytic variant, was similar. The results obtained with three other group-III strains were the same 
HAEMOLYSIS BY E. COLI

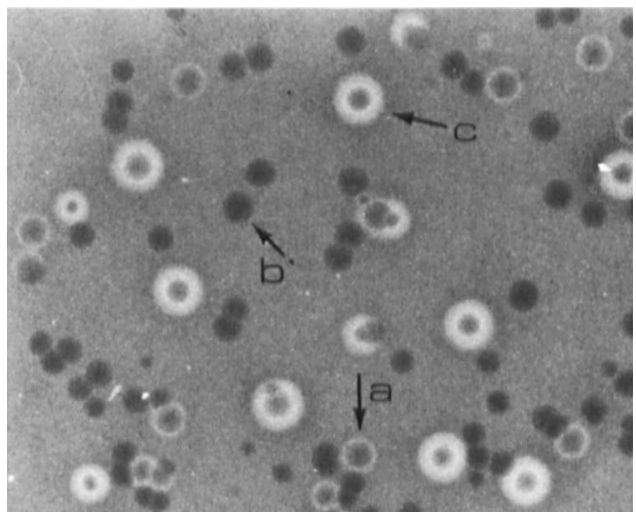

FIG. 2.-Different types of altered haemolysis on blood agar: $\mathrm{c}=$ unchanged haemolysis (control); $\mathrm{a}=$ colony showing reduced haemolytic activity; $\mathrm{b}=$ nonhaemolytic colony. 

TABLE III

Effect of reduction and elimination of haemolysin production on the virulence of mouse-nephropathogenic group-II strains

\begin{tabular}{|c|c|c|c|c|c|c|}
\hline $\begin{array}{c}\text { Ex coli } \\
\text { strain no. } \\
\text { and variant* }\end{array}$ & $\begin{array}{c}\text { Haemolysis } \\
\text { on } \\
\text { blood agar } \dagger\end{array}$ & $\begin{array}{c}\alpha \text {-Haemolytic } \\
\text { activity } \\
\text { (dilution) } \dagger\end{array}$ & Serotype & $\begin{array}{c}\text { Virulence } \\
\text { group } \ddagger\end{array}$ & $\begin{array}{c}\text { Time } \\
\text { to } \\
\text { death§ }\end{array}$ & $\begin{array}{c}\text { Haemo- } \\
\text { globinuria }\end{array}$ \\
\hline $\begin{array}{l}\text { AD 109 } \\
\text { AD 109a } \\
\text { AD } 109 b \\
\text { AD } 109 c\end{array}$ & $\begin{array}{c}+++ \\
++ \\
- \\
+++\end{array}$ & $\begin{array}{c}32 \\
16 \\
\text { Absent } \\
64\end{array}$ & $\begin{array}{l}\mathrm{O} 75: \mathrm{K}^{-} \\
\mathrm{O} 75: \mathrm{K}^{-} \\
\mathrm{O} 75: \mathrm{K}^{-} \\
\mathrm{O} 75: \mathrm{K}^{-}\end{array}$ & $\begin{array}{l}\text { II } \\
\text { I } \\
\text { I } \\
\text { II }\end{array}$ & $\begin{array}{c}<8 \mathrm{~h} \\
4 \mathrm{~d}-<14 \mathrm{~d} \\
4 \mathrm{~d}-<14 \mathrm{~d} \\
<8 \mathrm{~h}\end{array}$ & $\begin{array}{l}+ \\
- \\
- \\
+\end{array}$ \\
\hline $\begin{array}{l}\text { AD1 10 } \\
\text { AD1 10a } \\
\text { AD1 10b } \\
\text { AD1 10c }\end{array}$ & $\begin{array}{r}++ \\
++ \\
+ \\
+++\end{array}$ & $\begin{array}{c}64 \\
4 \\
\text { Absent } \\
32\end{array}$ & $\begin{array}{l}\mathrm{O} 6: \mathrm{K} 2 \\
\mathrm{O} 6: \mathrm{K} 2 \\
\mathrm{O} 6: \mathrm{K} 2 \\
\mathrm{O} 6: \mathrm{K} 2\end{array}$ & $\begin{array}{l}\text { II } \\
\text { I } \\
\text { I } \\
\text { II }\end{array}$ & $\begin{array}{l}8 \mathrm{~h}-<1 \mathrm{~d} \\
\text { avirulent } \\
\text { avirulent } \\
8 \mathrm{~h}-<1 \mathrm{~d}\end{array}$ & $\begin{array}{l}- \\
- \\
- \\
-\end{array}$ \\
\hline $\begin{array}{l}\text { AD111 } \\
\text { AD111a } \\
\text { AD111c }\end{array}$ & $\begin{array}{c}+++ \\
+ \\
+++\end{array}$ & $\begin{array}{c}16 \\
\text { Absent } \\
16\end{array}$ & $\begin{array}{l}\mathrm{O} 6: \mathrm{K} 2 \\
\mathrm{O} 6: \mathrm{K} 2 \\
\mathrm{O} 6: \mathrm{K} 2\end{array}$ & $\begin{array}{l}\text { II } \\
\text { I } \\
\text { II }\end{array}$ & $\begin{array}{l}1 \mathrm{~d}-<4 \mathrm{~d} \\
\text { avirulent } \\
1 \mathrm{~d}-<4 \mathrm{~d}\end{array}$ & $\begin{array}{l}+ \\
- \\
-\end{array}$ \\
\hline $\begin{array}{l}\text { AD113 } \\
\text { AD113a } \\
\text { AD113c }\end{array}$ & $\begin{array}{r}+++ \\
++ \\
+++\end{array}$ & $\begin{array}{r}128 \\
8 \\
128\end{array}$ & $\begin{array}{l}\mathrm{O} 4: \mathrm{K} 3 \\
\mathrm{O} 4: \mathrm{K} 3 \\
\mathrm{O} 4: \mathrm{K} 3\end{array}$ & $\begin{array}{l}\text { II } \\
\text { I } \\
\text { II }\end{array}$ & $\begin{array}{c}1 \mathrm{~d}-<4 \mathrm{~d} \\
\text { avirulent } \\
1 \mathrm{~d}-<4 \mathrm{~d}\end{array}$ & $\begin{array}{l}- \\
- \\
-\end{array}$ \\
\hline $\begin{array}{l}\text { AD27 } \\
\text { AD27b }\end{array}$ & ++ & $\begin{array}{c}256 \\
\text { Absent }\end{array}$ & $\begin{array}{l}\text { O139:K82 } \\
\text { O139:K82 }\end{array}$ & II & $\begin{array}{c}<8 \mathrm{~h} \\
\text { avirulent }\end{array}$ & + \\
\hline $\begin{array}{l}\text { AD310 } \\
\text { AD 310a } \\
\text { AD310b } \\
\text { AD310c }\end{array}$ & $\begin{array}{c}++ \\
++ \\
+ \\
+++\end{array}$ & $\begin{array}{c}128 \\
16 \\
\text { Absent } \\
128\end{array}$ & $\begin{array}{l}\mathrm{O} 6: \mathrm{K} 2 \\
\mathrm{O} \text { :K2 } \\
\mathrm{O} 6 \mathrm{~K} 2 \mathrm{~K} 2 \\
\mathrm{O} \text { : } \mathrm{K} 2\end{array}$ & $\begin{array}{l}\text { II } \\
\text { I } \\
\text { I } \\
\text { II }\end{array}$ & $\begin{array}{c}8 \mathrm{~h}-<1 \mathrm{~d} \\
4 \mathrm{~d}-<14 \mathrm{~d} \\
4 \mathrm{~d}-<14 \mathrm{~d} \\
8 \mathrm{~h}-<1 \mathrm{~d}\end{array}$ & $\begin{array}{l}+ \\
- \\
+\end{array}$ \\
\hline $\begin{array}{l}\text { AD336 } \\
\text { AD336b } \\
\text { AD336c }\end{array}$ & $\begin{array}{l}+++ \\
- \\
+++\end{array}$ & $\begin{array}{c}16 \\
\text { Absent } \\
16\end{array}$ & $\begin{array}{l}\text { O8:K25 } \\
\text { O8:K25 } \\
\text { O8:K } 25\end{array}$ & $\begin{array}{l}\text { II } \\
\text { II } \\
\text { II }\end{array}$ & $\begin{array}{c}1 \mathrm{~d}-<4 \mathrm{~d} \\
4 \mathrm{~d}-<14 \mathrm{~d} \\
1 \mathrm{~d}-<4 \mathrm{~d}\end{array}$ & $\begin{array}{l}- \\
- \\
-\end{array}$ \\
\hline
\end{tabular}

* $\mathbf{a}=$ Variant with reduced haemolytic activity; $\mathrm{b}=$ nonhaemolytic variant; $\mathrm{c}=$ control strain treated with curing agent but not changed in haemolytic activity. All variant strains were "cured" with actinomycin-D, except AD113 which was "cured" with rifampicin.

† See Methods.

† See footnote to table I.

$\S$ See footnote to table II.

(table IV). Reducing or abolishing the haemolysin production of group-III strains produced a small decrease in killing time for the mice (fig. 4 and table IV). Furthermore, three of the four haemolytic group-III strains gave rise to haemoglobinuria in the mice, whereas most of the variants with reduced haemolysin production did not.

In addition to the change in haemolytic activity, some strains lost their $\mathrm{K}$ antigen after treatment with actinomycin-D or rifampicin. We isolated variants with reduced haemolytic activity from the group-III strains AD117 and $\mathrm{AD} 121$, both $\mathrm{O} 6: \mathrm{K} 23$, that no longer produced $\mathrm{K}$ antigen. These $\mathrm{K}^{-}$ variants behaved as avirulent group-I strains. From strain AD118, also $\mathrm{O} 6: \mathrm{K} 23$, we isolated a variant with reduced haemolytic activity that we presumed had a smaller amount of $\mathrm{K} 23$ antigen because the unheated culture was agglutinated with $\mathrm{O} 6$ antiserum but still reacted with $\mathrm{K} 23$ antiserum. This variant behaved as an avirulent group-I strain. 


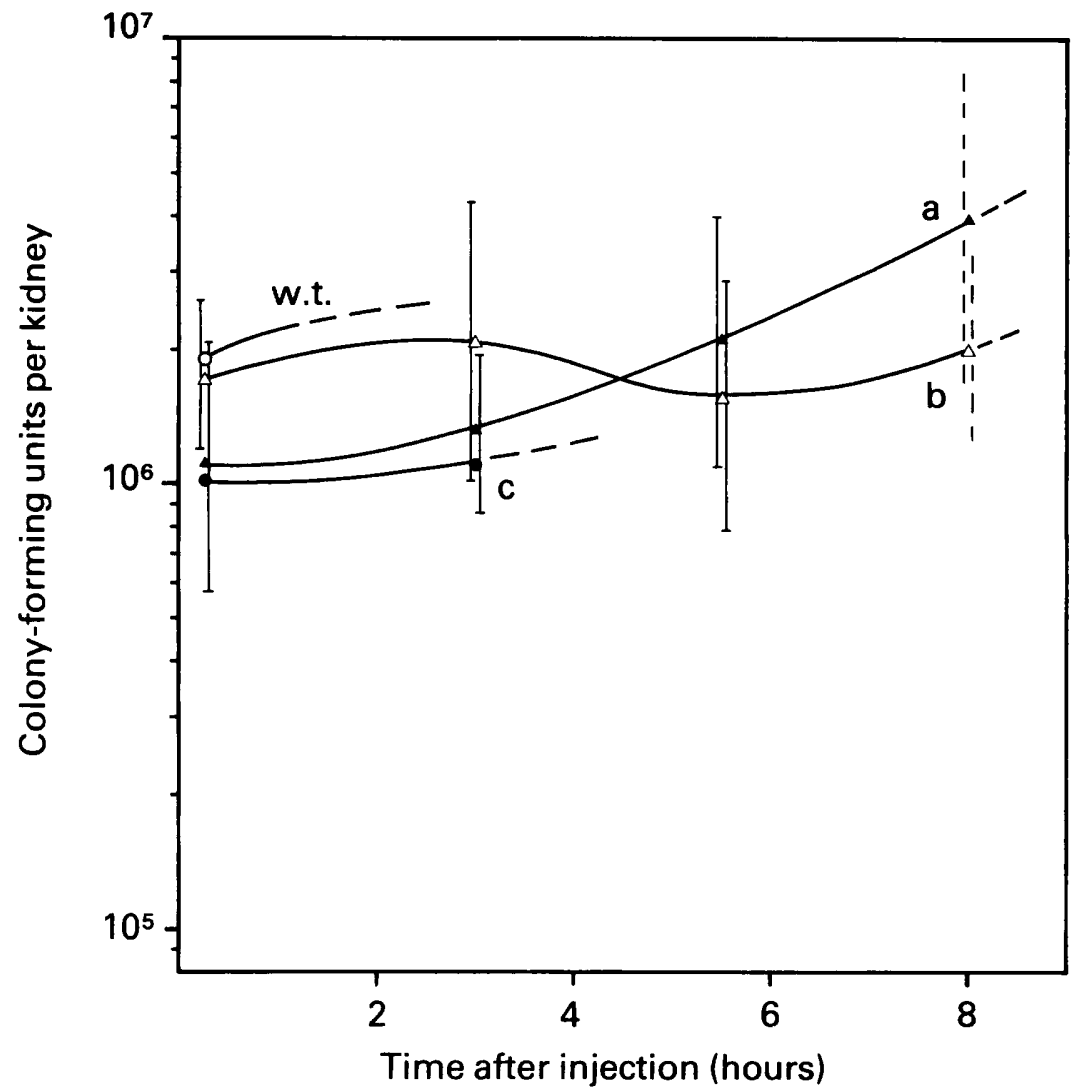

FIG. 4.-Effect of reduction and elimination of haemolysin production on the virulence of group-III strain AD121 for the mouse kidney. w.t. = Wild type haemolytic strain; $a=$ variant with reduced haemolytic activity; $b=$ nonhaemolytic variant; $c=$ control strain with no change in haemolysis.

TABLE IV

Effect of reduction and elimination of haemolysin production on the virulence of group-III strains

\begin{tabular}{|c|c|c|c|c|c|c|}
\hline $\begin{array}{c}\text { E. coli } \\
\text { strain no. } \\
\text { and variant* }\end{array}$ & $\begin{array}{l}\text { Haemolysis } \\
\text { on } \\
\text { blood agar† }\end{array}$ & $\begin{array}{c}\alpha \text {-Haemolytic } \\
\text { activity } \\
\text { (dilution) } \dagger\end{array}$ & Serotype & $\begin{array}{c}\text { Virulence } \\
\text { group } \ddagger\end{array}$ & $\begin{array}{l}\text { Time } \\
\text { to } \\
\text { death } \S\end{array}$ & Haemoglobinuria \\
\hline $\begin{array}{l}\text { AD117 } \\
\text { AD117a } \\
\text { AD117b } \\
\text { AD } 117 \mathrm{c}\end{array}$ & $\begin{array}{c}+++ \\
++ \\
+ \\
+++\end{array}$ & $\begin{array}{c}32 \\
8 \\
\text { Absent } \\
32\end{array}$ & $\begin{array}{l}\text { O6:K23 } \\
\text { O6:K } 23 \\
\text { O6:K23 } \\
\text { O6:K23 }\end{array}$ & $\begin{array}{l}\text { III } \\
\text { III } \\
\text { III } \\
\text { III }\end{array}$ & $\begin{array}{c}<8 \mathrm{~h} \\
<8 \mathrm{~h} \\
8 \mathrm{~h}-<1 \mathrm{~d} \\
<8 \mathrm{~h}\end{array}$ & $\begin{array}{l}+ \\
+ \\
+ \\
+\end{array}$ \\
\hline $\begin{array}{l}\text { AD118 } \\
\text { AD118b } \\
\text { AD118c }\end{array}$ & $\begin{array}{l}+++ \\
- \\
+++\end{array}$ & $\begin{array}{c}32 \\
\text { Absent } \\
32\end{array}$ & $\begin{array}{l}\mathrm{O} 6: \mathrm{K} 23 \\
\mathrm{O} 6: \mathrm{K} 23 \\
\mathrm{O} 6: \mathrm{K} 23\end{array}$ & $\begin{array}{l}\text { III } \\
\text { III } \\
\text { III }\end{array}$ & $\begin{array}{c}<8 \mathrm{~h} \\
8 \mathrm{~h}-<1 \mathrm{ld} \\
<8 \mathrm{~h}\end{array}$ & $\frac{+}{+}$ \\
\hline $\begin{array}{l}\text { AD119 } \\
\text { AD 119b } \\
\text { AD 119c }\end{array}$ & $\begin{array}{l}+++ \\
+ \\
++\end{array}$ & $\begin{array}{l}256 \\
\text { Absent } \\
256\end{array}$ & $\begin{array}{l}\text { O18:K? } \\
\text { O18:K? } \\
\text { O18:K? }\end{array}$ & $\begin{array}{l}\text { III } \\
\text { III } \\
\text { III }\end{array}$ & $\begin{array}{c}<8 \mathrm{~h} \\
8 \mathrm{~h}-<1 \mathrm{~d} \\
<8 \mathrm{~h}\end{array}$ & $\begin{array}{l}- \\
- \\
-\end{array}$ \\
\hline $\begin{array}{l}\text { AD 121 } \\
\text { AD 121a } \\
\text { AD 121b } \\
\text { AD 121C }\end{array}$ & $\begin{array}{c}++ \\
++ \\
- \\
+++\end{array}$ & $\begin{array}{c}16 \\
8 \\
\text { Absent } \\
16\end{array}$ & $\begin{array}{l}\text { O6:K23 } \\
\text { O6:K23 } \\
\text { O6:K23 } \\
\text { O6:K23 }\end{array}$ & $\begin{array}{l}\text { III } \\
\text { III } \\
\text { III } \\
\text { III }\end{array}$ & $\begin{array}{c}<8 \mathrm{~h} \\
8 \mathrm{~h}-<\mathrm{ld} \\
<8 \mathrm{~h} \\
<8 \mathrm{~h}\end{array}$ & $\begin{array}{l}+ \\
- \\
- \\
+\end{array}$ \\
\hline
\end{tabular}

* See footnote $(*)$ to table III.

$\dagger$ See Methods. $\ddagger$ See footnote to table I.

$\S$ See footnote to table II. 


\section{Discussion}

The present results lead us to conclude that haemolysin production in urinary strains of $E$. coli is a virulence factor of importance for some virulent strains. In all strains, haemolysis contributed to the toxicity for mice, but only in most of the mouse nephropathogenic group-II strains did it seem to be a decisive factor for virulence. Previously we have shown that group-II strains are frequently found among $E$. coli strains isolated from the urine of patients with acute pyelonephritis or asymptomatic bacteriuria, less often among isolates from acute cystitis and not among faecal isolates (van den Bosch et al., $1980 a, 1981$ ). Therefore, we consider that haemolysis by $E$. coli plays a role in the pathogenesis of upper urinary tract infections, but that other virulence factors must be involved also. Six out of 17 group-II strains were nonhaemolytic, and the virulence of one of the seven haemolytic group-II strains was not affected by elimination of the haemolysin production. Furthermore, four avirulent group-I strains were haemolytic. Haemolysis did not seem to be an important virulence factor for the more virulent group-III strains found amongst acute pyleonephritis, acute cystitis and faecal isolates (van den Bosch et al., 1980a 1981). However, the present study indicates that the K23 antigen may be a virulence factor in some group-III strains.

Our present finding that $\alpha$-haemolysin production by urinary strains of $E$. coli contributed to their toxicity for mice, but seemed to be a decisive virulence factor only in some nephropathogenic group-II strains is consistent with other investigations. There is epidemiological evidence that haemolysin production is a virulence factor in the pathogenesis of urinary-tract infection (Dudgeon $e t$ al., 1921, 1922; Cooke and Ewins, 1975; Minshew et al., 1978a and b), and Fried et al. (1971) found an association between haemolysin production by $E$. coli and the ability to produce pyelonephritis in mice and rats after intravenous injection. Several studies have shown the association of $\alpha$ haemolysin with general toxicity and necrotoxicity for various animals, and with cytotoxicity for various cells (Smith, 1963; Smith and Halls, 1967; Chaturvedi et al., 1969; Smith and Linggood, 1971; Cooke and Ewins, 1975; Kétyi et al., 1978; Minshew et al., 1978a and b; Emödy et al., 1979). However, Rennie and Arbuthnott (1974) did not find that purified $\alpha$ haemolysin was toxic for mice and rabbits after intravenous injection, in contrast with the results obtained with crude $\alpha$-haemolysin preparations (Smith, 1963; Smith and Halls, 1967). This indicates that another toxin, closely correlated with $\alpha$ haemolysin, might be involved.

In the present study we found that haemolysin production by $E$. coli was easily eliminated in most cases by treatment with actinomycin-D or rifampicin which suggests that the haemolysin production was plasmid mediated. Several studies have indicated that haemolysin production in most haemolytic strains of E. coli is mediated by a Hly plasmid (Smith and Halls, 1967; Goebel and Schrempf, 1971; Smith and Linggood, 1971; Goebel et al., 1974). However, Hull et al. (1980) recently found evidence that in one E. coli strain haemolysin production is chromosomal, and Minshew et al. (1978a) suggested that the 
haemolysin of most extraintestinal strains is not plasmid mediated. We have not shown that our strains were cured of a Hly plasmid, although the frequencies of elimination suggest this.

Treatment of haemolytic strains with an agent of known curing activity (Mitchell and Kenworthy, 1977) frequently resulted in the appearance of two types of colony with altered haemolysin production: a nonhaemolytic variant and a variant with reduced haemolytic activity (fig. 2). Hull et al. (1980) also found these two variants after treatment of one strain with a chemical mutagen. We cannot explain this phenomenon because all but one of the variants with reduced haemolytic activity had not lost the ability to produce either $\alpha$ or $\beta$ haemolysin; neither can we explain the contradiction between our finding that variants of group-II strains that showed reduced $\alpha$-haemolytic activity behaved as avirulent group-I strains, and our finding, also described by Smith and Linggood (1971), that $\alpha$-haemolytic activity did not seem to affect the virulence of wild-type haemolytic strains. It is possible that an $E$. coli strain could produce several different $\alpha$-haemolysins at the same time, all of which may not be relevant to virulence.

We are very grateful to P. A. M. Guinée and W. H. Jansen, National Institute of Public Health, Bilthoven, The Netherlands, for checking the serotypes of our strains. The skilled technical assistance of W. F. Schouten with the animal experiments is acknowledged, and we thank P. A. R. Koopman, Department of Medical Statistics, Free University, for statistical analysis and helpful discussions.

\section{REFERENCES}

Chaturvedi, U. C., Mathur, A., Khan, A. M. and Mehrotra, R. M. L. 1969. Cytotoxicity of filtrates of haemolytic Escherichia coli. J. med. Microbiol., 2, 211.

COOKE, E. M. AND EwINS, S. P. 1975. Properties of strains of Escherichia coli isolated from a variety of sources. J. med. Microbiol., 8, 107.

Dudgeon, L. S., Wordley, E. AND Bawtree, F. 1921. On Bacillus coli infections of the urinary tract, especially in relation to haemolytic organisms. J. Hyg., Camb., 20, 137.

Dudgeon, L. S., WORDley, E. AND BAWTREe, F. 1922. On Bacillus coli infection of the urinary tract especially in relation to haemolytic organisms (second communication). J. Hyg., Camb., 21, 168.

EMÖDY, L., KÉTYI, I., KUCH, B. AND PÁCSA, S. 1979. Antitoxic immunity against the so-called lung toxin produced by Escherichia coli. Acta microbiol. hung., 26, 233.

Fried, F. A., Vermeulen, C. W., Ginsburg, M. J. and Cone, C. M. 1971. Etiology of pyelonephritis: further evidence associating the production of experimental pyelonephritis with hemolysis in Escherichia coli. J. Urol., 106, 351.

GoEbel, W., RoYer-PoKora, B., Lindenmaier, W. AND BUJARd, H. 1974. Plasmids controlling synthesis of hemolysin in Escherichia coli: molecular properties. J. Bact., 118, 964.

GOEBEL, W. AND SCHREMPF, H. 1971. Isolation and characterization of supercoiled circular deoxyribonucleic acid from beta-hemolytic strains of Escherichia coli. J. Bact., 106, 311.

Hull, R. A., Hull, S. I., Minshew, B. H. AND FalKow, S. 1980. Genetics of hemolysin of Escherichia coli. In Current chemotherapy and infectious diseases, edited by J. D. Nelson and C. Grassi, American Society for Microbiology, Washington, DC, Volume II, p. 1283.

Jorgensen, S. E., Short, E. C., Kurtz, H. J., Mussen, H. K. And Wu, G. K. 1976. Studies on the origin of the $\alpha$-haemolysin produced by Escherichia coli. J. med. Microbiol., 9, 173.

Kétyi, I., Emödy, L., Kontrohr, T., Ver tényi, A., PÁcsa, S., Avdeeva, T. A., Safonova, N. V. AND Golutova, N. K. 1978. Mouse lung oedema caused by a toxic substance of Escherichia coli strains. Acta microbiol. hung., 25, 307. 
Lovell, R. AND ReEs, T. A. 1960. A filterable haemolysin from Escherichia coli. Nature, Lond., 188, 755.

Minshew, B. H., Jorgensen, J., Counts, G. W. and Falkow, S. 1978a. Association of hemolysin production, hemagglutination of human erythrocytes, and virulence for chicken embryos of extraintestinal Escherichia coli isolates. Infect. Immun., 20, 50.

Minshew, B. H., JoRgensen, J., Swanstrum, M., Grootes-Reuvecamp, G. A. and Falkow, S. 1978b. Some characteristics of Escherichia coli strains isolated from extraintestinal infections of humans. J. infect. Dis., 137, 648.

MitChell, I. DE G. AND KeNWORTHY, R. 1977. Attempted elimination of plasmid-determined haemolysin, K88 antigen and enterotoxin from Escherichia coli pathogenic for pigs. $J$. appl. Bact., 42, 207.

Rennie, R. P. AND ARbuthnott, J. P. 1974. Partial characterisation of Escherichia coli haemolysin. J. med. Microbiol., 7, 179.

ShORT, E. C. AND KURTZ, H. J. 1971. Properties of the hemolytic activities of Escherichia coli. Infect. Immun., 3, 678 .

Sмith, H. W. 1963. The haemolysins of Escherichia coli. J. Path. Bact., 85, 197.

Smith, H. W. AND Halls, S. 1967. The transmissible nature of the genetic factor in Escherichia coli that controls haemolysin production. J. gen. Microbiol., 47, 153.

SmITH, H. W. AND LINGGOOD, M. A. 1971. Observations on the pathogenic properties of the K88, Hly and Ent plasmids of Escherichia coli with particular reference to porcine diarrhoea. J. med. Microbiol., 4, 467.

SNYDER, I. S. AND KoCH, N. A. 1966. Production and characteristics of hemolysins of Escherichia coli. J. Bact., 91, 763.

VAN DEN BosCh, J. F., DE GraAFF, J. AND MaCLaREN, D. M. 1979. Virulence of Escherichia coli in experimental hematogenous pyelonephritis in mice. Infect. Immun., 25, 68.

van den Bosch, J. F., Oe, P. L., Postma, P., De Graaff, J., Maclaren, D. M., Jansen, W. H. AND GUINÉE, P. A. M. 1980a. Virulence of Escherichia coli in acute pyelonephritis, acute cystitis and asymptomatic bacteriuria. Antonie van Leeuwenhoek, 46, 321.

van den Bosch, J. F., Postma, P., De GraafF, J. and Maclaren, D. M. $1980 b$. Determination of the $\alpha$-haemolytic activity of haemolytic urinary Escherichia coli strains. FEMS Microbiol. Lett., 8, 75 .

van den Bosch, J. F., Postma, P., van Brenk, D., Guinée, P. A. M., de Graaff, J. and MACLAREN, D. M. 1981. Virulence of Escherichia coli strains isolated from urine of patients with acute cystitis and from faeces of healthy women. Antonie van Leeuwenhoek, 47 , in press.

van den Bosch, J. F., Verboom-Sohmer, U., Postma, P., de Graaff, J. and MacLaren, D. M. 1980c. Mannose-sensitive and mannose-resistant adherence to human uroepithelial cells and urinary virulence of Escherichia coli. Infect. Immun., 29, 226.

Williams, P. H. 1979. Determination of the molecular weight of Escherichia coli $\alpha$-haemolysin. FEMS Microbiol. Lett., 5, 21.

ZWADYK, P. AND SNYDER, I. S. 1971. Purification and kinetic studies of the hemolysin from Escherichia coli. Can. J. Microbiol., 17, 741. 
